\title{
Attitudes toward climate change: major emitters in southwestern Kansas
}

\author{
Lisa M. B. Harrington* \\ Department of Geography, Kansas State University, Manhattan, Kansas 66506-0801, USA
}

\begin{abstract}
As part of an initiative to improve understanding of place-to-place differences in greenhouse gas emissions, local changes in radiative forcing, and mitigative potential, the attitudes of decision-makers in the major greenhouse-gas-emitting industries in a 6-county study area in southwestern Kansas were investigated. This study included both mailed questionnaire and unstructured interview techniques, with quantitative and qualitative components. The information obtained from one method tended to corroborate data obtained from the other. Results indicate that, in this area, many respondents in the best positions to take mitigative actions are unconvinced of human-induced climate change. There are some variations among industries, with those involved in natural gas or electricity provision least convinced of potential negative impacts related to greenhouse gas emissions/climate change. In this region, it would appear that better communication of 'proof' of human climate impacts, as well as mitigative opportunities, would be a necessary part of encouraging industries to take action.
\end{abstract}

KEY WORDS: Attitudes $\cdot$ Climate change $\cdot$ Mitigation $\cdot$ Local places $\cdot$ Global warming

\section{INTRODUCTION}

One possible response to environmental change is to adapt: to implement social and economic adjustments that tend to minimize negative impacts without necessarily doing anything directly to slow or halt the change itself. Adaptation sometimes is seen as the reasonable response to climate change, especially when the assumption is made that change will happen fairly gradually (Kates 1997). Another response is to take actions that reduce, or mitigate, environmental change. Mitigation of human-induced climate change includes direct actions to reduce greenhouse gas emissions and actions to increase carbon sequestration through land cover change. A third possibility is, of course, the 'business as usual' (Watson et al. 1996a, Houghton 1997, Parker \& Blodgett 1998) or 'do nothing' option normally included in planning documents and scenario development. This option would be acceptable only if the potential for harm from environmental change falls within tolerable limits.

${ }^{*}$ E-mail: lharrin@ksu.edu
Because the likelihood of human-induced climate change through greenhouse gas emissions is widely accepted in the scientific community (Houghton et al. 1996, Fletcher 1997), it often is assumed that mitigative actions are desirable (Kates 1997). Many reports on climate change focus on potential mitigative actions, although adaptive actions also are described (e.g., US EPA 1990, Nakičenovič 1993, Watson et al. 1996a,b, Houghton et al. 1997). Adaptation is presented as a likely future necessity, even if mitigation occurs at Kyoto Protocol levels (Parry et al. 1999).

Assessment of the potential either for adaptation to possible climate change or for mitigation of greenhouse gas emissions requires an understanding of current views of citizens and representatives of business communities. Attempts to assess public views of climate change have been made at the national scale or through occasional urban case studies (e.g., Kempton 1991a,b, 1997, Bostrom et al. 1994, Read et al. 1994, Berk \& Schulman 1995, Bord et al. 1998, Krosnick et al. 1998, O'Connor et al. 1999).

Top-down, or national-scale, research and policy approaches may not be sufficient to achieve desirable un- 
derstanding of and social responses to environmental problems. Investigation of conditions, attitudes, and understanding in local areas is desirable because greenhouse gas emissions, potential effects, and possible responses vary from place to place, and because mitigation must take place through local action (see, e.g., Dow 1992, Agyeman et al. 1998, Easterling et al. 1998, Kates \& Torrie 1998, Kates et al. 1998, Yarnal 1998, Wilbanks \& Kates 1999). This study adds to the growing body of knowledge related to mitigative/adaptive potential by providing results of a survey of major emitters in southwestern Kansas. Research into climate change attitudes has not considered particular industries or more rural places. This study addresses views in industry and in a specific, relatively rural, area.

\section{STUDY AREA AND PURPOSE}

The southwestern Kansas study area is comprised of 6 counties (Finney, Ford, Gray, Haskell, Seward, and Meade), covering about $14000 \mathrm{~km}^{2}$. The total population was about 92800 in 1990, but has grown to near 100000 . The 3 largest communities are Garden City, Liberal, and Dodge City, with populations between 16000 and 25000 . Agriculture-related activities are central to the economy of the region; in this area, agricultural production focuses on animal agriculture dominated by beef cattle feedlots. Much of the crop-based agriculture is for animal feed and is dependent on irrigation from the Ogallala aquifer. Other agriculturerelated activities include meat processing, farm equipment sales, and agricultural support services. The natural gas industry also is significant to the area. Local production feeds into pipelines and associated compressor stations transport natural gas pumped from extensive gas fields in Kansas, Oklahoma, and Texas.

A number of aspects of greenhouse gas emissions and climate change have been investigated for this area (e.g., AAG in press, Angel et al. 1998, Easterling et al. 1998, Goodin et al. 1998, Kates et al. 1998, Harrington et al. 1999, Wilbanks \& Kates 1999, DeHart \& Soulé 2000). The objective of this paper is to examine attitudes toward climate change and potential mitigation among individuals from the businesses associated with high levels of greenhouse gas emissions in the Kansas study area.

The major greenhouse gas-producing economic sectors or activities in southwestern Kansas, in decreasing order of $\mathrm{CO}_{2}$ equivalent emissions (1990 estimates), are (1) electrical power generation; (2) natural gas extraction and transport; (3) concentrated animal agriculture; and (4) transportation, particularly the trucking industry (Goodin et al. 1998, also see Kates et al. 1998). Surveys of these major greenhouse gas produc- ers, supplemented by interviews, were important in assessing local attitudes toward climate change.

\section{INTERVIEWS}

Interviews of local leaders can yield information about the outlook or attitudes of those in the best positions to pursue and/or influence change in a local area. Research in southwestern Kansas included personal interviews with decision-makers in the identified major greenhouse gas-producing industries and individuals who occupied positions related to community leadership and decision-making. The research team, consisting of 5 faculty members and 2 doctoral students, conducted face-to-face field interviews dealing with greenhouse gas knowledge and mitigation potential in August and November 1998. Personal interviews of selected individuals, as well as comments made at a forum hosted by an electric power corporation, enabled acquisition of more specific and detailed information that often is not accessible through questionnaires alone, and gave a broader perspective on the thinking of local economic and political leaders. Interview data are based on conversations with 22 individuals (Table 1).

Table 1. Interviewee positions. Positions shown total more than the 22 individuals included: some interviewees hold more than one position. These are shown separately to protect privacy. Specific individuals were identified through contacts with companies and organizations in the study area; a limited number had cooperated with prior (unrelated) studies. Interviewees are in decision-making positions, although specific positions are not shown to protect privacy. One interview was made by telephone. One additional potential natural gas interviewee declined to be interviewed

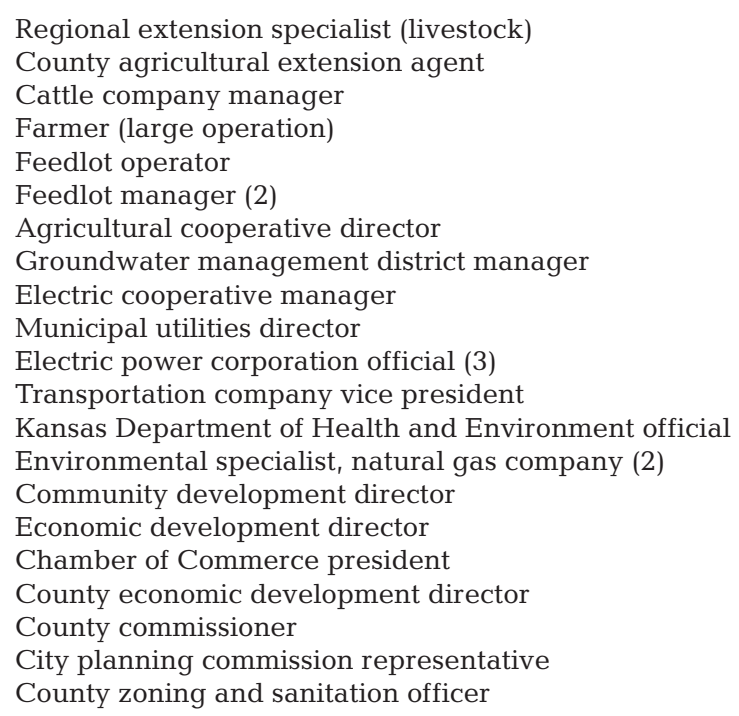


Table 2. Climate change questionnaires, southwestern Kansas study area

\begin{tabular}{|lccccc|c|}
\hline \multicolumn{1}{c}{ Industry/households: } & Electric & Natural gas & Feedlot & Transport & Industry total & Households \\
\hline Number mailed & 12 & 67 & 55 & 48 & 182 & 702 \\
Number deliverable & 12 & 65 & 55 & 42 & 174 & 384 \\
Usable response rate (\%) & 50 & 36 & 44 & 26 & 37 & 34 \\
& $(\mathrm{n}=6)$ & $(\mathrm{n}=23)$ & $(\mathrm{n}=24)$ & $(\mathrm{n}=11)$ & $(\mathrm{n}=64)$ & $(\mathrm{n}=199)$ \\
\hline
\end{tabular}

The interviews were 'unstructured,' or relatively informal discussions. Interviews included 4 general topics for discussion: (1) concern with climate change issues, (2) strategies for decreasing greenhouse gas emissions, (3) desirable locus of control for mitigation activities, and (4) awareness of emissions-reducing technology. Specific questions varied depending on circumstances, and some interchange of ideas and information occurred during the process as interviewers also responded to questions. It was explained that these interviews were part of a larger effort (AAG in press), and interviewers expressed interest in understanding varying opinions regarding the topics.

In the interviews, answers to the second and fourth topics above became intertwined; because these appear to be inherently interrelated, this paper reviews combined interview and questionnaire results under 3 headings: (1) level of concern with climate change, (2) awareness and adoption of means to reduce greenhouse gas emissions, and (3) the desirable level of 'control' for mitigation activities. Generalizations based on the responses reflect both the individual thinking of interviewees and their impressions of the attitudes of others living in the study area.

\section{QUESTIONNAIRES}

The views of a larger group were sought through 4 questionnaire-based surveys conducted in late 1998/ early 1999. A total of 182 surveys were sent to members of the 4 industries identified as the most important greenhouse gas emitters in the study area. Although their enterprises are active in the study area, not all respondents work in the 6 counties. Questionnaires were mailed to representatives of all members of identifiable 'populations' within the 4 most important greenhouse gas-emitting sectors. These ranged from 12 electric energy providers to 67 natural gas companies (Table 2). All identifiable trucking companies and all feedlots of at least 1000 head capacity were included. Potential respondents were lower than expected in the transportation industry, apparently due to a number of trucking companies having gone out of business. After an initial mailing, a reminder postcard was mailed 1 week later to those who had not yet responded. This was followed after 2 more weeks by a second questionnaire, and then a last reminder postcard. Based on 174 deliverable sector surveys, the overall usable response rate was $35 \%$.

For comparison, data related to mid-1998 household surveys conducted in a similar mailed questionnaire format will be considered. The household surveys were conducted on a random-sample basis $(2.5 \%$ of 28443 households identified), and achieved a usable response rate of $34 \%{ }^{1}$

Survey questions were designed to assess the perceived gravity of global warming and willingness to take actions to reduce greenhouse gas emissions. Care was taken, in a cover letter, to explain that the wording of items on the questionnaires (which to some readers might appear 'biased' or 'loaded') did not necessarily reflect researcher opinions. ${ }^{2}$

In addition to questions with specific response options, surveys gave respondents the opportunity to make additional comments. Such comments contribute added insights as to the 'mindsets' of key persons in the study area. Respondents were told that 'Your [electricity-related, e.g.] company has been selected in a sample from six southwestern Kansas counties. We are asking professionals involved in the electric [or other] industry to provide us with information related to the industry, how it may change in the future, and opinions

${ }^{1}$ For each community of $\geq 100$ households, each 41 st household was sampled, beginning with one selected by random number (1 to 10). To ensure inclusion of smaller communities, 2 households were selected by random number for those communities with $<100$ households. Sampling was done with DeLorme Phone Search USA

${ }^{2}$ Please note that a number of questions are being used for comparability with other surveys conducted around the country and do not necessarily reflect opinions at Kansas State University.' To minimize any defensive reactions regarding questionnaire orientation, it was noted in the cover letter that 'Preliminary findings indicate that, while there have been substantial changes over the past 25 years, fewer greenhouse gases are released per square mile in southwestern Kansas than comparably sized areas in several other parts of the country.' Participation, whatever a respondent's views, also was encouraged with this statement: 'Your participation in this research is essential so that the voices of southwest Kansas are heard' 
concerning greenhouse gas emissions and climate change.' Individual questions did not specify whether respondents were to answer based on individual views or the 'company' view; focus on the individual industry was made clear, but certain questions obviously called for a personal perspective (see, e.g., Table 4). The degree to which the situation of a business influences employee perspectives, or the degree to which employee views shape company policy, is unknown. There also may be a relationship between an individual's attitudes and choice of employment. It is likely, however, that employees in management positions generally have a greater effect on company policy than other employees.

\section{RESULTS}

\subsection{Concern with climate change}

It is clear from interviews and questionnaire responses that climate change was not a major concern in the study area. There was some awareness of the issue, but on most lists of concerns it would rank very low. When given a variety of topics to rank by personal importance (e.g., reducing violent crime, having strong military, reducing poverty, having secure and loving marriage), 'slowing the rate of global warming' was ranked as least important, overall, by household respondents. Even among environmental matters, other topics were mentioned as higher priorities, par- ticularly concerns with water availability and local groundwater depletion, but also global population growth and soil erosion. Some people involved in greenhouse-gas-emitting activities focused on potential emissions benefits: carbon dioxide fertilization was associated with improved crop growth. This view was especially strong in the electricity industry.

The majority of questionnaire respondents in all industrial sectors said global warming due to fossil fuel combustion is an 'unproven theory' (Table 3). Twothirds of the natural gas producers and electric utility representatives believed that global warming is unproven. A clear majority believed that a relationship between fossil fuels and climate change is unproven. In contrast, household respondents from the study area were less likely to regard fossil-fuel-related climate change as an 'unproven theory' and more likely to regard it as a 'proven fact.' There is a significant difference between the industry respondents and the general population of the area.

The difficulties of making connections between this particular place-rural southwestern Kansas-and either an enhanced greenhouse effect or the conditions in far-off places creates perceptual difficulties with a need for mitigative actions. As one respondent put it, it is difficult to believe that feedlots in Kansas, for example, may affect climate in 'Timbuktu or New York.' Also, it may be recognized that certain activities either use energy or release gases, but potential connections to global climate change do not come to mind. Although feedlot operators know that there are

Table 3. Perceptions of reality and seriousness of 'global warming.' Values are percentages; totals may not add to $100 \%$ due to rounding. NR: no response

Would you say that it is mostly a proven fact that burning oil, coal, and natural gas for energy will cause global warming in the future, or that it is mostly an unproven theory?

\begin{tabular}{lccccc} 
& $\begin{array}{c}\text { Mostly an } \\
\text { unproven } \\
\text { theory }\end{array}$ & $\begin{array}{c}\text { Mostly a } \\
\text { proven } \\
\text { fact }\end{array}$ & $\begin{array}{c}\text { Somewhere between } \\
\text { unproven speculation } \\
\text { and proven fact }\end{array}$ & Other & Don't know \\
\hline Industry total $(\mathrm{n}=64)$ & 59.4 & 9.4 & 21.9 & 0 & 7.8 \\
Households $(\mathrm{n}=199)$ & 28.6 & 21.1 & 30.7 & 0.5 & 18.1 \\
\hline
\end{tabular}

Chi-square $=16.27, \mathrm{df}=2$, at 0.01 significance $(\mathrm{N}=217$; non-responses and 'don't know' omitted)

Some people think climate changes caused by global warming will be a serious problem for the world in the next $50-100$ years if no action is taken; others disagree. How serious a problem do you think such climate changes are likely to be?

\begin{tabular}{|c|c|c|c|c|c|c|}
\hline & $\begin{array}{l}\text { No problem } \\
\text { at all }\end{array}$ & $\begin{array}{l}\text { Slightly } \\
\text { serious }\end{array}$ & $\begin{array}{l}\text { Pretty } \\
\text { serious }\end{array}$ & $\begin{array}{c}\text { Very } \\
\text { serious }\end{array}$ & $\begin{array}{l}\text { Extremely } \\
\text { serious }\end{array}$ & NR \\
\hline Industry total $(\mathrm{n}=64)$ & 46.9 & 29.7 & 10.9 & 6.3 & 1.6 & 4.7 \\
\hline Household $(\mathrm{n}=199)$ & 14.6 & 25.1 & 31.7 & 20.6 & 5.5 & 2.5 \\
\hline
\end{tabular}


methane emissions associated with cattle, this wasn't necessarily mentally connected to climate change. 'It is my opinion that animals have very little to do with greenhouse gas or global warming,' according to one feedlot respondent. Changes to more efficient vehicles or other energy savings were not always recognized as means to reduce greenhouse gas emissions.

There were concerns that greater regulation of greenhouse gas emissions would do harm to specific industries without addressing a real problem. Interviews indicated that these worries are particularly evident among individuals associated with the electricity and natural gas industries, and with economic development. Overall, interviewees stressed the need for proof of climate change for it to receive serious attention. Questionnaire respondents commented on a lack of belief in human effects on climate, or in 'the greenhouse effect,' for that matter:

- 'I'm not yet sold on climate change theories. I'm deeply concerned with the economics of doing something that would be of no help. ...'

(Electric utility respondent)

- 'I have not seen enough evidence to accept the Global Warming theory.'

(Feedlot respondent)

\section{- 'UNPROVEN THEORY!'}

(Transportation respondent)
- '... there has been too much publicity about it without scientific backup. ...'

(Feedlot respondent)

- 'The proposition that what mankind is doing in industry is causing climate changes has been proven false by a myriad of experienced scientists. ...'

(Natural gas respondent)

- 'There are scientific studies supporting the arguments for both sides of this issue. I don't believe there is enough supporting data for either side to prove their case. ...'

(Natural gas respondent)

In accordance with the doubts concerning human effects on climate, nearly half the questionnaire respondents from all emissions sectors anticipated global-warming-induced climate changes to be no problem for the world in the next 50 to $100 \mathrm{yr}$ (Table 3). There was a significant difference between industrial respondents and household respondents. Household respondents were much less likely to regard potential climate changes as 'no problem at all' and much more likely to view problems as 'pretty serious' to 'extremely serious.'

When asked about the effect global warming will have on the lives of themselves, their children, and grandchildren, a clear majority of industrial respondents foresaw 'very little' effect on themselves (Table 4). Fewer of these respondents anticipated 'very

Table 4. Perceptions of potential effects of 'global warming.' Values are percentages

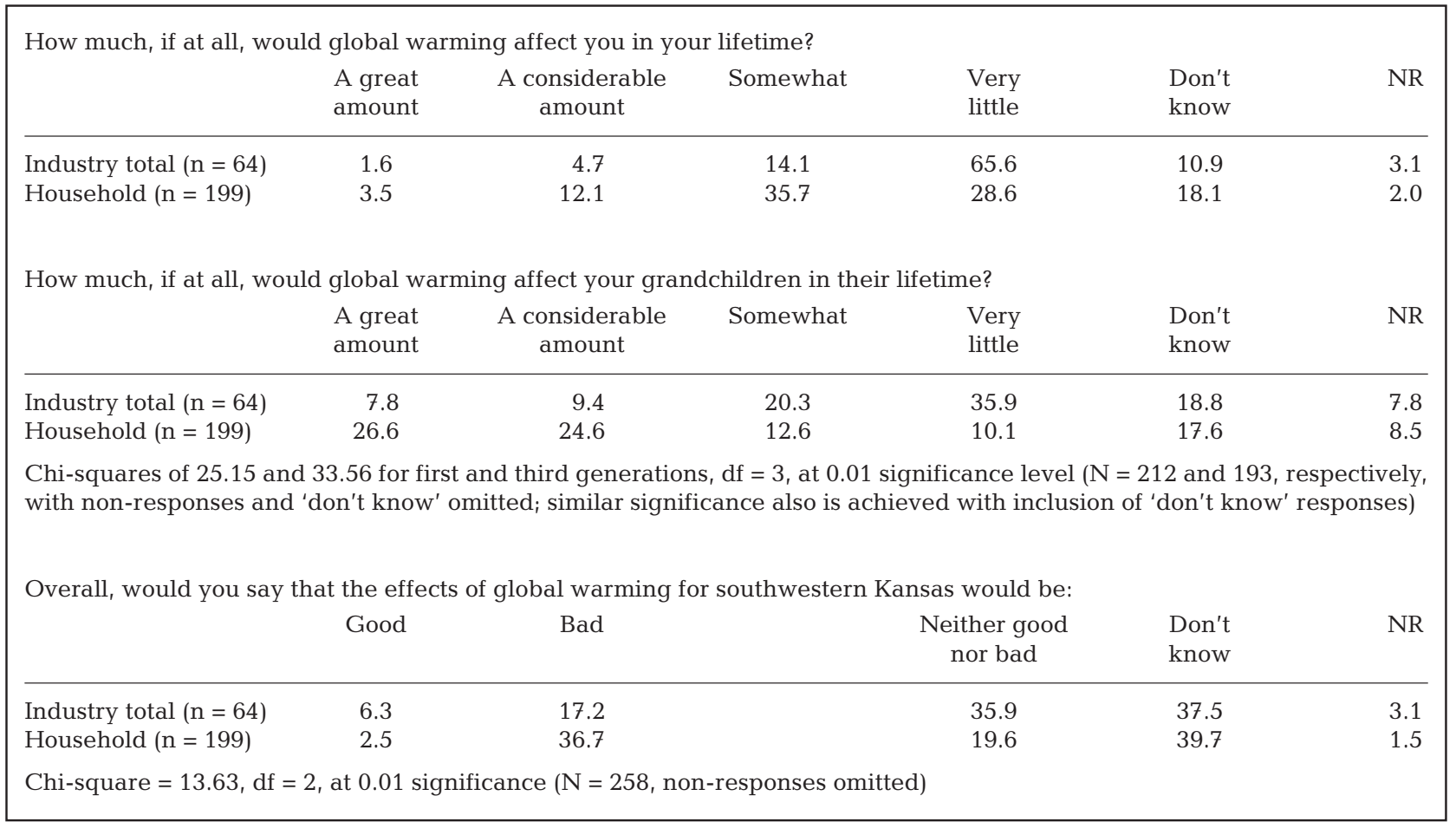


little' effect on their grandchildren. This contrasts with responses to the earlier question, where $47 \%$ of all major emissions sector respondents said that climate change would be 'no problem at all' for the world in the next 50 to 100 yr (Table 3). Responses also contrast with those of the general household group, where $29 \%$ expected 'very little' effect on themselves and $10 \%$ expected 'very little' effect on their grandchildren.

Only $6 \%$ of industry respondents expected 'a considerable amount' or 'a great amount' of effect on themselves, but $17 \%$ expected a 'considerable' or 'great' effect on their grandchildren. Uncertainty and perceptions of potential problems seem to intensify as the question becomes more personal, and especially as it extends to the next generations. However, for southwestern Kansas, a minority of industrial respondents envisioned 'considerable' to 'great' effects of global warming in 2 generations. Half the household respondents expected considerable to great effects on their grandchildren. Again, there are significant differences between respondents from major greenhouse-gas-emitting industries and the general local population.

When asked about future effects of global warming for southwestern Kansas, specifically, most industrial respondents said the effects would be 'neither good nor bad' or 'don't know.' Although mostly unwilling to say that climate change would be either favorable or unfavorable for the region, more respondents believed that results would be 'bad' than 'good.' Two of the 6 electric utility representatives said the effects of global warming for southwestern Kansas are likely to be good. Less than $5 \%$ of the respondents from the other industrial sectors believed this. Although the small number of responses calls for great caution, there are few electric utilities in the area and such views are important. Some electric utility representatives in southwestern Kansas have been active in promoting increased levels of $\mathrm{CO}_{2}$ as beneficial to plant growth, and they have strongly questioned the science behind global warming expectations.

Again, the general household survey indicates a significant difference from emissions sector responses. Twice as many household respondents as industrial respondents said that global warming effects in southwestern Kansas would be 'bad' (37 vs 17\%).

\subsection{Approaches to mitigation}

Knowledge of specific technologies and actions that could help to mitigate greenhouse gas releases was variable among interviewees. Those interviewees who are deeply involved with a specific enterprise often appeared quite well informed regarding technologies available. Such technologies may be oriented toward greater efficiency (and have an emissions reduction co-benefit), even if not intended specifically for greenhouse gas management.

Few companies have implemented actions to reduce greenhouse gas emissions (Table 5). Responses to interviews and questionnaires suggest that actions generally appear to have been taken for economic reasons or to meet government requirements, rather than as a response to climate concerns. Although it is likely that actions had been taken for other reasons, respondents recognized associated potential decreases in greenhouse gas emissions when answering questions.

Interviewee responses indicated that the best 'selling point' for any mitigation action is likely to be its economic benefits. Public relations was given by one interviewee as another potential reason for some mitigation actions. There is some participation in the US EPA (Environmental Protection Agency) Energy Star program for adoption of technologies for increased energy efficiency, and the Clean Air Act of 1990 was mentioned as promoting strategies to address greenhouse gas releases.

Questionnaire respondents were asked to indicate whether they favored, opposed or were indifferent to varying dollar amounts of increased operating costs to reduce global warming (Table 6). Overall, $45 \%$ of the industry representatives were opposed to any given increase in taxes and energy costs. According to one natural gas respondent: 'We are a very environmentally aware company and are willing to take any measures necessary to ensure that we have a great place for our children and grandchildren to live in, but we will not spend money to reduce greenhouse emissions.'

Table 5. Has your company implemented any actions in southwestern Kansas to reduce greenhouse gas emissions?

\begin{tabular}{|c|c|c|c|}
\hline Industry & Yes & No & Actions listed as taken \\
\hline Natural gas & 3 & 20 & $\begin{array}{l}\text { Methane leakage surveys, efficient equipment, lean burn technology on compressors, new } \\
\text { compressor units, 'green' light bulbs, emissions control devices }\end{array}$ \\
\hline Electricity & 2 & 4 & Investment in pollution controls, load control \\
\hline Feedlots & 1 & 23 & Solid material distribution and decomposition, wastewater distribution \\
\hline Transport & 2 & 9 & Clean burning engines, fuel efficient engines, cut idle time \\
\hline
\end{tabular}


Table 6. Industrial 'willingness to pay' for alternate technologies through taxes and energy expenses $(\mathrm{N}=64$ for each row). Values are percentages

\begin{tabular}{|c|c|c|c|c|c|}
\hline Amount & Favor & Oppose & Neither favor nor oppose & Don't know & NR \\
\hline$\$ 85$ & 18.8 & 45.3 & 7.8 & 12.5 & 15.6 \\
\hline$\$ 250$ & 15.6 & 46.9 & 9.4 & 12.5 & 15.6 \\
\hline$\$ 500$ & 14.1 & 50.0 & 6.3 & 12.5 & 17.2 \\
\hline$\$ 1000$ & 12.5 & 57.8 & 4.7 & 10.9 & 14.1 \\
\hline$\$ 5000$ & 6.3 & 60.9 & 9.4 & 7.8 & 15.6 \\
\hline
\end{tabular}

\subsection{Level of control}

There was a substantial attitude of resistance to government (or 'United Nations') involvement and potential costs, as well as some expression of faith in 'market forces' among questionnaire respondents:

- '... Market forces will limit fossil fuel consumption far more effectively and efficiently than government intervention.'

(Natural gas respondent)

- 'Government will screw up about anything they get involved with, and they'll do it with Global Warming. ...'

(Feedlot respondent)

- 'Costs of most things are high enough without added (unnecessary) cost of added regulations.'

(Electric utility respondent)

- '...we should avoid requesting government intervention for any short term relief. We should allow market conditions to finally control the industry.'

(Natural gas respondent)

- '... Compliance on a worldwide basis will be negligible. US producers will face more off the wall mandates that at current product prices they can't afford.'

(Natural gas respondent)

- '... I'M AFRAID IT APPEARS YOU HAVE BEEN DUPED BY THE "UNITED NATIONS" AND ALL OF THEIR LEFT WING ENVIRONMENTAL EXTREMISM!!!'

(Feedlot respondent)

As indicated by face-to-face interviews, the local majority opinion was that, if control is to be exerted, it should be at the local or regional level. A need for some federal or state level oversight was recognized by interviewees, but the federal government, in particular, was seen as capricious in policy development and implementation and inconsistent in year-to-year legislation. The EPA was seen as inflexible and as an administrator of edicts. 'Unfunded mandates' were an especially sensitive area.
In spite of these general attitudes, some interviewees thought that there is too much potential for decisions to be dominated by local interests to leave all control at the local level: local control is too 'corruptible.' In other words, local self-interest can lead to poor decisions relative to the global atmospheric/climatic commons. Some interviewees in the natural gas industry expressed a preference for state- and federal-level control, however, partly as a matter of convenience or familiarity. Cooperation between locals and government agencies was more desirable than the imposition of regulations, and respondents desired goals set from the 'bottom-up' or 'middle-down.' Actively seeking trade organization participation could be very important.

A need for outside expertise and the desirability of demonstration projects and joint ventures, with the involvement of government and educational institutions, were recognized by respondents. State university scientists are seen as a source of expertise with which people in the study area would be comfortable, although there also was distrust of 'environmentalist' scientists and federally based researchers. Education and public information were stressed by interviewees. State Extension programs and local extension agents are highly trusted for information and education. As indicated by questionnaire responses and interviews, 'environmentalists' generally are not favorably regarded in southwestern Kansas.

\section{DISCUSSION}

Although vulnerability, a common topic in hazard and risk studies (Dow 1992, Cutter 1996), and uncertainty (Harper 1996) both are important themes in climate change research, this study indicates that decision-makers in southwestern Kansas are relatively unconcerned. According to Whyte (1985), 'scientific uncertainty and controversy become translated into 
public apathy in a world where problems compete for attention and resources.' Vulnerability, when it is a concern, is expressed more as a fatalistic view, where we will either adapt and survive, or succumb to forces beyond our control:

- 'I do not feel that global warming is a real hazard to the world today, or in the future. ... God created the earth, all of the creatures on it, and when it is out of control he will make the decision to change, not you, not me, or any other being on the face of the earth. ...'

(Feedlot respondent)

- 'I believe the human effects on climate are minuscule in comparison to the long term climatic variations over which we have no control. ...'

(Natural gas respondent)

In spite of such perceptions, interviews suggested that people tend to act on their own when convinced of a problem. Household recycling efforts were seen not as an 'environmentalist' action, but as prudent and waste-reducing. Most commonly mentioned was the abandonment of aerosol spray cans as reports in the media convinced people of problems. Some organizations have been influential in sustaining skepticism toward climate change in the area, however. The 'Greening Earth Society,' which supports increasing levels of $\mathrm{CO}_{2}$ to benefit plant growth, has become credible to electric utility personnel. To date, mitigative actions related to greenhouse gas emissions have not gained wide support.

Other studies have indicated that a majority of the American population 'believe in' global warming, would be willing to pay more for utilities in order to reduce 'air pollution,' and want governments and businesses to take action to reduce potential global warming (e.g., Krosnick et al. 1998). The views of representatives of greenhouse-gas-producing industries in southwestern Kansas do not reflect these larger findings for the American public, indicating, instead, disbelief in the concept of global climate change, lack of willingness to pay for actions meant to reduce greenhouse gas emissions, and resistance to further government interference with business. In fall 1997 and winter 1997-98 telephone surveys of 'representative national cross-sections,' Krosnick et al. (1998) found that over $70 \%$ of their interviewees believed that global warming had been occurring and would continue to occur unless addressed. Majorities also believed that the effects of global warming would be bad (58 to $61 \%$ ), and that the US government should do 'a great deal' or 'quite a bit' to combat global warming (57 to $59 \%)$. $^{3}$ Over $70 \%$ expressed willingness to pay higher utility bills (Krosnick et al. 1998). In com-

${ }^{3}$ Response ranges reflect the 2 interviews periods, bracketing a period of active media coverage parison, only $9 \%$ of the representatives of the major greenhouse-gas-producing industries in southwestern Kansas expressed belief in the idea that fossil fuel use would cause global warming, and a majority $(77 \%)$ believed that it would be no problem or 'slightly' serious for the world in the next 50 to $100 \mathrm{yr}$. Although there were significant differences between industry and household respondents, both groups in southwestern Kansas appeared to have less belief in potential 'bad' effects of global warming than the Krosnick et al. (1998) national sample. Research by Bord et al. (1998) indicated that the 'perceived threat [from global warming] is relatively low in the United States.' This appears to be especially true of the southwestern Kansas greenhouse gas emitters.

Bord et al. (1998) conducted a residential mail survey across the 48 contiguous states in spring 1997 and considered a variety of other national and international surveys. Although studies frequently indicate public concern with global warming, the authors warn that the apparent high levels of concern likely are related to a tendency to provide 'socially desirable' responses to environmental questions, and that the real level of concern may be more shallow. If (1) the responses given by greenhouse-gas-producing industry respondents in southwestern Kansas also reflect a tendency to indicate greater concerns about environmental issues than actually are felt or (2) potential respondents who were skeptical of the 'global warming' topic opted to not participate in the survey, then the views among industry groups may be even more resistant to mitigation actions than questionnaire responses indicate. Respondents often expressed doubt regarding global climate change and concern about the costs of addressing what to many of them is a questionable issue. Responses therefore may have been relatively unaffected by a tendency toward 'socially desirable' questionnaire responses.

\section{CONCLUSIONS}

Climate change is not a major concern among representatives of greenhouse-gas-producing industries in this rural area of Kansas. There is some belief that the global climate change issue is real, but in these enterprises, individuals accepting climate change are a minority. To some, 'global warming' is a real concern; to others, it is an 'interesting' subject; and to still others, it is unproven and of no concern. (In reality, to the latter group the issue of climate change may be a real concern, but not because they believe human-induced climate change is occurring. Rather, climate change is a concern to this group because it represents a potential for further regulation, in spite of a lack of accepted 
'proof.') Greenhouse gas producers of southwestern Kansas do not see themselves as contributors either to a problem or to a solution.

Responses indicate significant differences between the views of those in decision-making positions in greenhouse-gas-emitting industries and the general population of the study area. There are, of course, a range of beliefs among members of both groups, but the general population overall consistently displays a higher level of concern with climate change or 'global warming' than industry representatives. While such differences may be a part of 'common wisdom,' specific evidence of public-industrial perceptual contrasts has been in short supply. Although the public in the study area appears to be more concerned with climate change than industry representatives, they also appear to be less convinced of a potential problem than the national public. Because these results specifically relate to a particular, limited area of the US, further investigation of variation in attitudes or beliefs - from place to place and from group to group-are warranted.

There is a lack of perceived connection between gas emissions in the study area and an enhanced greenhouse effect, as well as a lack of connection between activities in southwestern Kansas and other world locales. However, as Berk \& Schulman (1995) put it, 'insofar as global climate change occurs, it will be experienced and evaluated locally.' Likelihood of adoption of mitigation strategies is dampened by the attitude that greenhouse gas emissions and climate change concerns are not local issues. It is important to remember that these particular findings apply specifically to the most important greenhouse-gas-emitting enterprises in southwestern Kansas. For climate change to receive serious attention in southwestern Kansas, much stronger 'proof' is expected. Other research has shown that 'risk perceptions and knowledge increase people's willingness to take steps that address environmental problems' (O'Connor et al. 1999). However, skepticism among many of the respondents, particularly in industry, seems to be firmly entrenched. It will be extremely difficult to achieve a level of 'proof' that would convince many of the industry respondents of a need for action.

Professionals are aware of current technologies that could be used to reduce greenhouse gas emissions in specific types of enterprises, but there is a general perceptual disconnect between energy efficiency and greenhouse-gas-emissions reduction and, therefore, climate change. Some respondents link greater energy efficiency with emissions reductions when asked questions that lead them to think about such connections, but the link does not appear to be recognized when individuals take action to increase efficiency.
Given that state university scientists and extension specialists were mentioned several times as sources or potential sources of information, additional 'outreach' activities by such individuals may have the best chance of affecting perceptions and influencing mitigative action in the region. Mitigative activities are most likely where other benefits (e.g., greater efficiency and lower costs, meeting state or national environmental requirements, or enhanced public relations) are evident. Understanding of local variations in climate change perceptions and receptivity to mitigative actions may help in tailoring approaches not only to locally important greenhouse gas sources, but also to the mindsets of decision-makers in order to more effectively address concerns.

Acknowledgements. Thanks to KSU Global Change in Local Places (GCLP) team members D. G. Goodin, J. A. Harrington, Jr., S. L. Kaktins, D. E. Kromm, S. E. White, and B. Witcher for interview and data management work. R. Abler, S. Cutter, R. Kates, and T. Wilbanks were 'driving forces' behind the GCLP project (AAG in press, Cutter et al. in press). GCLP participants at Appalachian State University, Pennsylvania State University, and the University of Toledo conducted related work. Comments by the reviewers and editor Brent Yarnal were appreciated. Supported by grants from NIGEC, the National Institute for Global Environmental Change (LTW 62123-06519), and from NASA, through the Association of American Geographers (NAGW-4932).

\section{LITERATURE CITED}

AAG (Association of American Geographers) (in press) Global Change in Local Places Research Group. Global change in local places: estimating, understanding, and reducing greenhouse gas emissions. Cambridge University Press, New York

Agyeman J, Evans B, Kates RW (1998) Editorial: Greenhouse gases special: Thinking locally in science, practice and policy. Local Environ 3(3):245-246

Angel DP, Attoh S, Kromm D, DeHart J, Slocum R, White S (1998) The drivers of greenhouse gas emissions: What do we learn from local case studies? Local Environ 3(3): 263-277

Berk RA, Schulman D (1995) Public perceptions of global warming. Clim Change 29:1-33

Bord RJ, Fisher A, O'Connor RE (1998) Public perceptions of global warming: United States and international perspectives. Clim Res 11:75-84

Bostrom A, Morgan MG, Fischoff B, Read D (1994) What do people know about global climate change? 1. Mental models. Risk Anal 14(6):959-970

Cutter SL (1996) Vulnerability to environmental hazards. Prog Human Geogr 20(4):529-539

Cutter SL, Mitchell JT, Hill A, Harrington L, Kaktins S, Muraco W, DeHart J, Reynolds A, Shudak R (in press) Attitudes toward reducing greenhouse gas emissions from local places. In: Global change in local places: estimating, understanding, and reducing greenhouse gas emissions. AAG Global Change in Local Places Research, Cambridge University Press, New York

DeHart J, Soulé PT (2000) Does I=PAT work in local places? Prof Geogr 51(1):1-10 
Dow K (1992) Exploring differences in our common future(s): the meaning of vulnerability to global environmental change. Geoforum 23(3):417-436

Easterling WE, Polsky C, Goodin D, Mayfield MW, Muraco WA, Yarnal B (1998) Changing places, changing emissions: the cross-scale reliability of greenhouse gas emission inventories in the US. Local Environ 3(3):247-262

Fletcher SR (1997) Global climate change treaty: summary of the Kyoto Protocol. Congressional Research Service Report for Congress. 98-2 ENR. The National Council for Science and the Environment, Washington, DC (accessed: December 22, 1999) available at http://www.cnie.org/ nle/clim-3.html

Goodin DG, Harrington JA Jr, Holden GI Jr, Witcher BD (1998) Local greenhouse gas emissions in southwestern Kansas. Gr Plains Res 8:231-253

Harper CL (1996) Environment and society: human perspectives on environmental issues. Prentice Hall, Upper Saddle River, NJ

Harrington JA Jr, Goodin D, Witcher B (1999) Variation in greenhouse gas emissions across western Kansas. Preprints, Tenth Global Change Symposium, American Meteorological Society, Dallas, TX, p 458-461

Houghton J (1997) Global warming: the complete briefing, 2nd edn. Cambridge University Press, Cambridge

Houghton JT, Meira Filho LG, Callander BA, Harris N, Kattenberg A, Maskell K (eds) (1996) Climate change 1995: the science of climate change. The Second Assessment Report of the Intergovernmental Panel on Climate Change. Cambridge University Press, Cambridge

Houghton JT, Meira Filho LG, Griggs DJ, Maskell K (eds) (1997) Stabilization of atmospheric greenhouse gases: physical, biological and socio-economic implications. IPCC Technical Paper III. Intergovernmental Panel on Climate Change. Cambridge University Press, Cambridge

Kates RW (1997) Climate change 1995: impacts, adaptations, and mitigation (review). Environment 39(9):29-33

Kates RW, Torrie RD (1998) Global change in local places. Environment 40(2):5,39-41

Kates RW, Mayfield MW, Torrie RD, Witcher B (1998) Methods for estimating greenhouse gases from local places. Local Environ 3(3):279-297

Kempton W (1997) How the public views climate change. Environment 39(9):12-21

Kempton W (1991a) Lay perspectives on global climate

Editorial responsibility: Brent Yarnal,

University Park, Pennsylvania, USA change. Global Environ Change 1(3):183-208

Kempton W (1991b) Public understanding of global warming. Soc Nat Resour 4:331-345

Krosnick JA, Visser PS, Holbrook AL (1998) American opinion on global warming: the impact of the fall 1997 debate. Resources 133:5-9

Nakičenovič N (guest ed) (1993) Energy 18(5). (Issue on longterm strategies for mitigating global warming)

O'Connor RE, Bord RJ, Fisher A (1999) Risk perceptions, general environmental beliefs, and willingness to address climate change. Risk Anal 19(3):461-471

Parker L, Blodgett J (1998) Global climate change: reducing greenhouse gases-how much from what baseline? Congressional Research Service Report for Congress. 98-235 ENR. The National Council for Science and the Environment, Washington, DC (accessed: March 11, 2000) available at http://www.cnie.org/nle/clim-13.html

Parry M, Arnell N, Hulme M, Martens P, Nicholls R, White A (1999) Viewpoint - the global impact of climate change: a new assessment. Global Environ Change 9:S1-S2

Read D, Bostrom A, Morgan MG, Fischoff B, Smuts T (1994) What do people know about global climate change? 2 . Survey studies of educated lay people. Risk Anal 14(6): 971-982

US EPA (United States Environmental Protection Agency) (1990) Policy options for stabilizing global climate: Report to Congress. US EPA, Washington, DC

Watson RT, Zinyowera MC, Moss RH (eds) (1996a) Climate change 1995: impacts, adaptations and mitigation of climate change: scientific-technical analyses. The Second Assessment Report of the Intergovernmental Panel on Climate Change. Cambridge University Press, Cambridge

Watson RT, Zinyowera MC, Moss RH (eds) (1996b) Technologies, policies and measures for mitigating climate change. IPCC Technical Paper 1. Intergovernmental Panel on Climate Change. Cambridge University Press, Cambridge

Whyte AVT (1985) Perception. In: Kates RW, Ausubel JH, Berberian M (eds) Climate impact assessment: studies of the impact of climate and society. SCOPE 27. Wiley, Chichester, p 403-436

Wilbanks TJ, Kates RW (1999) Global change in local places: how scale matters. Clim Change 43(3):601-628

Yarnal B (1998) Integrated regional assessment and climate change impacts on river basins. Clim Res 11:65-74

Submitted: March 7, 2000; Accepted: September 10, 2000

Proofs received from author(s): November 15, 2000 